Nowoczesne Systemy Zarządzania

Zeszyt 12 (2017), nr 4 (październik-grudzień)

ISSN 1896-9380, s. 93-104

Modern Management Systems

Volume 12 (2017), No. 4 (October-December)

ISSN 1896-9380, pp. 93-104
Instytut Organizacji i Zarządzania

Wydział Cybernetyki

Wojskowa Akademia Techniczna

w Warszawie

Institute of Organization and Management

Faculty of Cybernetics

Military University of Technology

\title{
Menedżerowie personalni (HR) w organizacji zhierarchizowanej
}

\author{
Personal managers (HR) \\ in a hierarchical organization
}

\author{
Kazimierz Piotrkowski \\ Wojskowa Akademia Techniczna
}

\begin{abstract}
Abstrakt. Tematyka artykułu obejmuje istotne zagadnienie dotyczące istoty pracy, miejsca, roli i profesjonalizacji menedżerów personalnych kierujących komórkami kadrowymi w strukturze organizacyjnej Sił Zbrojnych RP. W pierwszej części publikacji przedstawiono istotę pracy menedżerów (kierowników personalnych) pełniących funkcje kierownicze. Druga część dotyczy problematyki miejsca i podległości komórek personalnych, jakimi są wydziały, działy bądź sekcje w strukturze organizacyjnej - zwane najczęściej jednostką wojskową. Natomiast w trzeciej części wskazano na konieczność profesjonalnego kształcenia osób mających podjąć pracę w komórkach personalnych jako oficerowie personalni w Siłach Zbrojnych RP. Słowa kluczowe: menedżer, funkcja personalna, zarządzanie kadrami.
\end{abstract}

Abstract: Focus article covers important issue on the substance of the work, the place, role and professionalization of personnel managers that guide cells in organizational structure including staff of the armed forces. In the first part of the publication shows the essence of the work of managers (personnel managers) officiating positions. The second part concerns the place and reporting personal cells which are departments, divisions or sections in organizational structure-called most military unit. However, in the third part indicated the need for professional training of people who have to work in personal calls as personalni officers in the armed forces.

Key words: manager, personnel function, HR management.

\section{Menedżer w strukturze organizacji}

Słowo „menedżer” jest bardzo często zamiennie stosowane z terminem „kierownik” bądź „lider”. Menedżera najczęściej postrzegamy jako zwierzchnika zespołu, odpowiadającego za osiągane przez jego członków efekty. Jego działania polegają na 
inspiracji, udzielaniu rad, wskazówek i informowaniu członków zespołu o osiąganych wynikach. Poprzez takie działanie rozwija ich kompetencje, co przekłada się na rezultaty organizacji i wynikające z tego korzyści dla pracowników.

W literaturze przedmiotu menedżerów najczęściej klasyfikujemy ze względu na miejsce zajmowane w hierarchii organizacji (szczebel, poziom organizacji) i obszary działania - rys. 1 (Gryffin, 2001, s. 45). Za kryterium różnicowania przyjmując wyłącznie miejsce menedżera w hierarchii zarządzania podmiotem gospodarczym, dokonuje się podziału kierowników na następujących poziomach:

- $\quad$ szczebel najwyższy (top management);

- $\quad$ szczebel średni (middle management);

- szczebel najniższy (junior management/first-line management) (Jarmołowicz, 2001, s. 130).

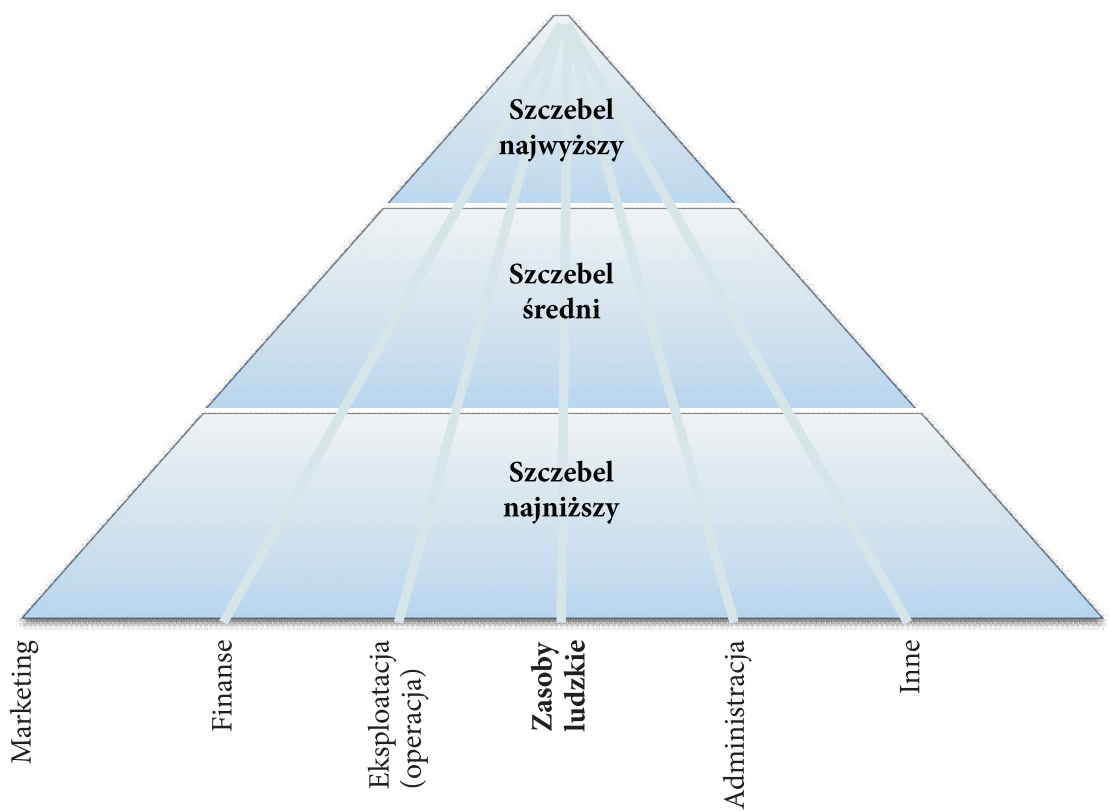

Rys. 1. Rodzaje menedżerów według obszarów działania i szczebla organizacji

Źródło: opracowanie własne na podstawie R.W. Griffin, Podstawy zarządzania organizacjami, Wyd. Naukowe PWN, Warszawa 2001, s. 45

Menedżerowie marketingu to kierownicy pracujący w dziedzinach związanych z funkcją marketingu i są odpowiedzialni za efekty pracy podległego mu zespołu, czyli za klientów i konsumentów zainteresowanych produktami bądź usługami organizacji, a także promocję, dystrybucję oraz rozwój nowych wyrobów.

Menedżerowie ds. finansów kierują zespołami zajmującymi się zasobami finansowymi organizacji. Odpowiadają głównie za zadania z obszaru rachunkowości, zarządzania finansami oraz inwestycji. 
Menedżerowie zarządzający zasobów ludzkich to najczęściej kierownicy działu kadr bądź kierownicy sekcji w dziale kadr odpowiadający za zatrudnienie, utrzymanie i rozwój pracowników. W szczególności zajmują się planowaniem zasobów ludzkich, doborem i rekrutacją pracowników, rozwojem kadr, projektowaniem systemów wynagrodzeń oraz premii, formułowaniem systemów oceny pracy, a także derekrutacją, czyli zwalnianiem pracowników z różnych przyczyn (np. odchodzą na emeryturę, osiągają słabe wyniki bądź też są problematyczni).

Menedżerowie administracyjni, zwani też menedżerami ogólnymi, nie mają określonej specjalności kierowniczej. Są nazywani menedżerami wszechstronnymi, dysponują znajomością różnych dziedzin funkcjonalnych zarządzania. Ich działalność polega na profesjonalnej obsłudze administracyjnej wszystkich podległych pracowników organizacji.

Menedżerowie inni to najczęściej kierujący zespołami specjalistycznymi w nowoczesnych organizacjach. Ich stanowiska kierownicze nie dają się zaklasyfikować do jednej z wymienionych wyżej grup. Do takich menedżerów zaliczamy na przykład: menedżerów public relations czy menedżerów do spraw badań i rozwoju.

Bez względu na kryterium podziału menedżerów zawsze kierują oni pracą innych i są za nią odpowiedzialni. Profesjonalny menedżer to taki, który skutecznie realizuje wyznaczone cele oraz sprawnie, w sposób oszczędny i staranny, gospodaruje posiadanymi zasobami.

Menedżer to osoba, która jest odpowiedzialna za realizację procesu zarządzania, czyli planowanie, organizowanie, kierowanie ludźmi i kontrolowanie. Natomiast zarządzanie jest zestawem tych działań ukierunkowanych na zasoby organizacji, wykonywanych w zamiarze osiągnięcia jej celów w sposób sprawny i skuteczny. Do zasobów organizacji zaliczamy: zasoby ludzkie, finansowe, rzeczowe i informacyjne (rys. 1). Sprawność to właściwy sposób wykorzystywania zasobów (zgodny z regułami profesji, specjalistyczny, bez marnotrawstwa). Skuteczność jest działaniem z powodzeniem, robieniem tego, co należy robić w danych warunkach (Stoner, 2001, s. 20).

\section{Funkcja personalna w organizacjach zhierarchizowanych a zarządzanie kadrami}

W literaturze przedmiotu funkcja personalna (kadrowa) obejmuje ogół działań związanych $\mathrm{z}$ funkcjonowaniem ludzi $\mathrm{w}$ organizacji. W tak zwanej pragmatyce kadrowej praktyczna jej realizacja polega na efektywnym pozyskiwaniu, utrzymaniu i rozwoju zasobów ludzkich, czyli odnosi się do procesu zarządzania zasobami ludzkimi lub coraz częściej zarządzania kapitałem ludzkim. Tradycyjnie określana jest również jako zarządzanie personelem, potencjałem społecznym czy też kadrami. W zakres funkcji personalnej wchodzą czynności o charakterze wykonawczym, doradczym i regulacyjnym (Pocztowski, 2017, s. 7). 
W sprawowaniu funkcji personalnej kluczowym podmiotem jest wyspecjalizowana komórka organizacyjna zajmująca się określonymi działaniami kadrowymi zwanymi również personalnymi w zakresie pozyskania, utrzymania i rozwoju zasobów ludzkich. Dlatego też komórka ta powinna cechować się wysokim profesjonalizmem pracujących w niej osób. Komórki te najczęściej są określane jako: dział kadr, dział osobowy, dział zasobów ludzkich, dział personalny. Czasem używa się angielskiego skrótu i można spotkać nazwę dział HR (Piotrkowski, 2012, s. 98-99).

W Siłach Zbrojnych RP komórki kadrowe są ważnym ogniwem w realizacji funkcji personalnej w poszczególnych jednostkach organizacyjnych. Obecne zadania komórki personalnej wykraczają znacząco poza jej tradycyjną rolę, np. prowadzenie ewidencji pracowników, akt osobowych i wykonywanie innych zadań administracyjnych związanych z pracownikami. Od nowoczesnej komórki personalnej (menedżera i podległych mu pracowników) oczekuje się wypracowania, wdrożenia oraz realizacji strategii personalnej, przygotowania systemów operacyjnych i narzędzi kadrowych koniecznych do wypełniania wszystkich funkcji zarządzania zasobami ludzkimi oraz wspierania menedżerów liniowych (dowódców) w stosowaniu tych rozwiązań, a także profesjonalnego doradztwa w sprawach personalnych (Piotrkowski, 2012, s. 100-102). Komórki personalne (zwane również działami zasobów ludzkich) odgrywają kluczową rolę w nowoczesnej organizacji i są bardzo istotnym ogniwem zarządzania zasobami ludzkimi. Ich działalność oddziałuje na wszystkie elementy procesu kadrowego wynikające z najnowszej teorii i praktyki ząrzadzania. Jej realizacja wynika z założeń polityki kadrowej w Siłach Zbrojnych RP (Piotrkowski, 2012, s. 100-102). Umiejscowienie, podporządkowanie oraz wielkość tych komórek w hierarchii organizacji zależy od jej wielkości, zakresu zdecentralizowania jej działalności, rodzaju wykonywanej pracy (zadań) oraz rangi (znaczenia) przypisywanej funkcji personalnej (Piotrkowski, 2012, s. 99).

„Zarządzanie zasobami ludzkimi w siłach zbrojnych postrzega się jako strategiczne i spójne podejście wszystkich osób funkcyjnych do zarządzania ludźmi pełniącymi służbę wojskową (zatrudnionymi osobami), które indywidualnie i zbiorowo przyczyniają się do osiągania celów sił zbrojnych" (Ministerstwo Obrony Narodowej, Departament Kadr, 2010, www.kadry.wp.mil.pl).

\section{Miejsce działu HR w strukturach organizacyjnych sił zbrojnych}

Miejsce działów personalnych w strukturach organizacyjych Sił Zbrojnych RP jest uporządkowane i ujednolicone we wszystkich rodzajach wojsk. Działy personalne w siłach zbrojnych są ulokowane w pionie organizacyjnym szefa sztabu (zastępcy dowódcy) zaliczanym do dowództwa ${ }^{1}$ jako organu dowodzenia danej jednostki

1 Dowództwo - zespół ludzi, wraz z dowódcą, zajmujących się kierowaniem formacją wojskową lub zespołem ludzi. Najczęściej stosowane w terminologii wojskowej, rzadziej w terminologii cywilnej. 
organizacyjnej, czyli: dowództwa związków operacyjnych, oddziałów i pododdziałów w jednolitym układzie podlegającego bezpośrednio szefowi sztabu. Organ dowodzenia $^{2}$ to wyodrębniony pod względem strukturalnym i funkcjonalnym zespół o charakterze dowódczo-sztabowym powołany do przygotowania i zabezpieczenia realizacji decyzji dowódcy. Do dowództwa (organu dowodzenia) na szczeblu pododdziału zaliczamy: dowódcę, zastępcę dowódcy oraz szefa sztabu ${ }^{3}$ Komórki (działy personalne) w siłach zbrojnych są ulokowane w pionie organizacyjnym zastępcy dowódcy bądź szefa sztabu zaliczanego do dowództwa. W działach personalnych Sił Zbrojnych RP przyjęto następujące zasady ich oznaczeń:

\section{a) w Wojskach Ladowych}

- G-1 - od szczebla Dowództwa Komponentu Wojsk Lądowych do szczebla dywizji;

- S-1 - od szczebla brygady w dół;

b) $w$ Siłach Powietrznych

- A-1 - w Dowództwie Komponentu Sił Powietrznych;

- S-1 - od szczebla brygady i poniżej;

c) w Marynarce Wojennej:

- N-1 - od szczebla Dowództwa Komponentu Mrynarki Wojennej do szczebla flotylli;

- S-1 - od szczebla brygady (jednostki równorzędnej) do szczebla dywizjonu (batalionu);

d) J-1 - w Dowództwie Komponentu Wojsk Specjalnych.

2 Organ dowodzenia to dowództwo pododdziału, oddziału, związku taktycznego (kierownictwo instytucji) o charakterze dowódczo-sztabowym, któremu podlegają organizacyjnie jednostki wojskowe. Dowódcy pełniący funkcje dowódcze, stojący na czele organu dowodzenia, odpowiadają za całokształt działalności podległych im jednostek, mają prawo rozkazywania im oraz podejmowania decyzji o ich użyciu. Sztab pododdziału, oddziału, związku taktycznego jest głównym organem dowodzenia dowódcy. W. Auerbach, Leksykon wiedzy wojskowej, MON, Warszawa 1979, s. 287.

3 Dowódca (ang. commander) - stanowisko etatowe w wojsku, żołnierz stojący na czele rodzaju sił zbrojnych, związku taktycznego, oddziału lub pododdziału. Posiada określone prawa (wydawanie rozkazów oraz nadzór nad ich wykonawstwem). Jest organizatorem działań bojowych podległych wojsk (żołnierzy) oraz dowodzi nimi w czasie ich trwania (Wikipedia). Dowódca jest najważniejszą osobą określonego dowództwa szczebla taktycznego. W określonej strukturze organizacyjnej podlegają mu bezpośrednio - oprócz zastępcy, szefa sztabu oraz grupy dowódcy - również dowódcy oddziałów (brygad, pułków, pododdziałów) lub pododdziałów (batalionu, dywizjonu kompanii), w zależności od szczebla organizacyjnego. Dowódca posiada uprawnienia do wydawania rozkazów wszystkim, żołnierzom i pracownikom cywilnym wojska. $Z$ racji zajmowanej najwyższej funkcji w hierarchii organizacji ma prawo wydawać rozkazy, wytyczne, polecenia i instrukcje we wszystkich sprawach dotyczących danego szczebla organizacyjnego. Na co dzień kieruje działalnością z pomocą zastępcy i szefa sztabu przez wyznaczanie zasadniczych celów, stawianie zadań i egzekwowanie ich wykonania, stwarzając jednocześnie podwładnym warunki zapewniające niezbędną samodzielność działania oraz pełne wykorzystanie ich inicjatywy. J. Kręcikij, J. Wołejszo (red.), Podstawy dowodzenia, Akademia Obrony Narodowej, Warszawa 2007, s. 204. 
Komórka personalna w strukturze organizacyjnej poszczególnych rodzajów wojsk występuje zawsze jako pierwsza. I tak w wojskach lądowych G-1 lub S-1, w Siłach Powietrznych A-1 i S-1, w Marynarce Wojennej N-1 i S-1 oraz w wojskach specjalnych J-1 i S-1. Natomiast w batalionie realizującym zadania poza granicami kraju mogą występować bardziej rozbudowane poszczególne komórki dowództwa, jak również stanowić wydzieloną grupę specjalistyczną (Kręcikij, 2007, s. 201). Każda z komórek organizacyjnych spełnia określoną funkcję, począwszy od szczebla najwyższego do szczebla (poziomu) najniższego, oczywiście tam, gdzie one wystepują. W strukturach organizacyjnych sił zbrojnych komórki (działy) personalne sa organami odpowiedzialnymi za zarządzanie zasobami ludzkimi w zakresie: uzupełniania stanów osobowych, prowadzenia działalności organizacyjno-etatowej, kształtowania wysokiego poziomu dyscypliny i odpowiedniego morale, czuwania nad przestrzeganiem prawa, porządku i przepisów, bezpieczeństwa i poziomu dyscypliny. Natomiast do szczegółowych przedsięwzięć wymienionych powyżej organów (komórek) w zakresie działań kadrowych należy przede wszystkim:

- $\quad$ analizowanie i planowanie oraz realizacja przedsięwzięć dotyczących ukompletowania dowództwa i podległych oddziałów (pododdziałów), przebiegu służby żołnierzy, jak również prowadzenie ewidencji stanu osobowego;

- $\quad$ sporządzanie zapotrzebowania na żołnierzy rezerwy w celu ukompletowania dowództwa i oddziałów (pododdziałów);

- opracowywanie rozkazów personalnych;

- prowadzenie spraw personalnych żołnierzy zawodowych;

- zbieranie i opracowywanie oraz przedstawienie dowódcy wniosków i propozycji (dowódców-przełożonych) w sprawach wyznaczenia żołnierzy na stanowiska, przenoszenia i mianowania na kolejne stopnie wojskowe;

- planowanie, koordynacja, organizacja i prowadzenie działalności wychowawczej;

- $\quad$ inicjowanie przedsięwzięć profilaktycznych sprzyjających wzrostowi dyscypliny wojskowej, analizowanie jej stanu, określanie zagrożeń dla wykonania zadań oraz sposobów przeciwdziałania im;

- rozpoznanie, analiza nastrojów, opinii i postaw żołnierzy, przedstawienie stosownych wniosków dowódcy w tym zakresie;

- sprawowanie fachowego nadzoru nad działalnością personalno-wychowawczą w podległych oddziałach (pododdziałach).

Należy podkreślić, że usytuowanie (pośrednie podporządkowanie) organu odpowiedzialnego za sprawy kadrowe w strukturze wszystkich jednostek organizacyjnych nie wpływa korzystnie na sprawność działań personalnych. Skoro za decyzje personalne odpowiedzialny jest dowódca, to działy personalne HR powinny być wyłączone $\mathrm{z}$ pionu szefa sztabu (zastępcy dowódcy) i bezpośrednio podporządkowane dowódcy danej jednostki organizacyjnej. Obecnie takie ulokowanie działów HR świadczy o niezbyt wysokiej randze i znaczeniu czynnika ludzkiego 
w Siłach Zbrojnych RP. Przedstawiając miejsce i główne zadania poszczególnych organów podległych szefowi sztabu, autor chciał wyeksponować organ zajmujący się sprawami personalnymi jako wiodący (najważniejszy).

\section{Rola działu HR w siłach zbrojnych}

Formalnie role i zadania działów HR (organów kadrowych) w siłach zbrojnych są określone w formie sformalizowanych dokumentów przez Departament Kadr Ministerstwa Obrony Nrodowej na podstawie stanu prawnego (ustawy, akty wykonawcze) regulującego działalność kadrową w danym okresie ${ }^{4}$. Natomiast w codziennej pragmatyce (działalności) kadrowej role działów HR wynikają z zakresu ich zadań, czyli pełnionych funkcji jako określona komórka organizacyjna mająca swoje miejsce w hierarchii organizacji. Z tego wynika, że rola komórek kadrowych w procesie zarządzania zasobami ludzkimi w siłach zbrojnych przyjmuje konstrukt określonego modelu, który uwzględnia najnowszą wiedzę i praktykę z zakresu zarządzania. Dla potrzeb niniejszego opracowania przyjęto formę pełnienia tychże ról według własnego rozwiązania opartego na modelu D. Urlicha i A. Pocztowskiego, uwzględniając specyfikę badanej instytucji wojskowej. Główne komponenty tego modelu to:

- rola partnera strategicznego,

- rola eksperta od zarządzania,

- rola inspiratora w zaangażowaniu pracowników,

- rola animatora zmian,

- rola eksperta administracyjnego.

Charakterystykę komponentu przyjętego przez autora modelu przedstawiono na drodze własnych dociekań badawczych. Pierwszym z komponentów przyjętego modelu jest rola HR jako partnera strategicznego, gdzie określono stopień spełnienia tejże roli w organizacji w zakresie realizacji funkcji personalnej.

Jak wykazały badania, w siłach zbrojnych działy personalne według opinii $60 \%$ badanych występują w roli partnera strategicznego na średnim poziomie. Tylko niewielki odsetek (20\%) respondentów przypisuje im silną pozycję i duży wpływ na zarządzanie zasobami ludzkimi. Wynika to przede wszystkim ze stanu prawnego regulującego działalność kadrową oraz scentralizowanego systemu zarządzania kadrami w Siłach Zbrojnych RP (Piotrkowski, 2012, s. 98-101). Natomiast w ostatnich latach na podstawie dalszych dociekań badawczych nastąpił wzrost znaczenia działów personalnych (Piotrkowski, 2012, s. 97-99).

Uwarunkowania prawne pełnienia przez żołnierza zawodowego służby wojskowej, do których należą: Ustawa z dnia 11 września 2003 r. o służbie wojskowej żołnierzy zawodowych (DzU z 2008 r. nr 141, poz. 892 z późn. zm.); inne ustawy w liczbie ok. 20, akty wykonawcze wynikające z ustawy o służbie wojskowej żołnierzy zawodowych (64 akty wykonawcze). 
Rola działu HR jako eksperta od zarządzania przekładała się w wykorzystaniu wiedzy i umiejętności instytucji w realizacji określonej polityki personalnej. Dotyczy to przede wszystkim czynnego uczestnictwa w realizacji procesów zarządzania zasobami ludzkimi w sposób profesjonalny z określonymi standardami wynikającymi ze stanu prawnego regulującego działalność kadrową Sił Zbrojnych RP. Jak wykazały badania oddziaływania działów $\mathrm{HR}$, zdecydowanie mają one wpływ na proces pozyskiwania, wynagradzania, rozwoju zawodowego i przemieszczeń kadrowych, jak również na procesy pracy oraz projektowania struktur organizacyjnych. W praktyce dowódczej decyzje personalne podejmowane przez dowódców poszczególnych szczebli zarządzania są najczęściej konsultowane z szefami (kierownikami) działów personalnych z uwzględnieniem obowiązujących zasad pragmatyki kadrowej w określonym zakresie (Ministerstwo Obrony Narodowej, Departament Kadr, Warszawa, 2011). Natomiast w firmach taka zasada nie obowiązuje, dlatego też pracownicy działów HR odgrywają znacznie mniejszą rolę jako eksperci od zarządzania. Występuje większa swoboda w podejmowaniu decyzji przez kierowników poszczególnych szczebli zarządzania. Wynika to z większych uprawnień kierowników (menedżerów) niższych szczebli zarządzania, a przede wszystkim występuje znacznie większa tendencja decentralizacji procesów decyzyjnych, nie tylko w sprawach personalnych (Piotrkowski, 2012, s. 25-30).

Rola inspiratora w zaangażowaniu pracowników polega na współpracy szefów działów HR z osobami funkcyjnymi (dowódcami) poszczególnych jednostek organizacyjnych. Działy personalne w siłach zbrojnych odgrywają rolę inspiratorską w zaangażowaniu pracowników. Wskazują na to wyniki badań, gdzie $65 \%$ respondentów na poziomie dobrym i bardzo dobrym przypisuje im taką rolę (Piotrkowski, 2012, s. 109). Wynika to przede wszystkim z posiadanej wiedzy działów HR i określonych standardów, które stanowią pewne („nakreślone”) kierunki działania w zakresie zarządzania zasobami ludzkimi dla osób funkcyjnych poszczególnych szczebli zarządzania (Piotrkowski, 2016, s. 25-30).

Rola animatora zmian wiąże się $\mathrm{z}$ transformacją $\mathrm{i}$ inspirowaniem oraz wprowadzaniem zmian w kulturze organizacyjnej. Od 1989 roku siły zbrojne również podlegały dynamicznym przemianom. Zmiana społeczna w Polsce uruchomiła proces przemian w armii. Reformy te zdominowane zostały przez działania zmierzające do demokratyzacji, restrukturyzacji naszych sił zbrojnych, udziału w programie „Partnerstwo dla pokoju”, w konsekwencji wstąpienia do Sojuszu Północnoatlantyckiego oraz pełnego ich uzawodowienia (Walencik, 2002, s. 23-34). Proces przemian w dalszym ciągu trwa, czego dowodem jest zmiana systemu dowodzenia wprowadzona z dniem 1 stycznia 2014 roku oraz utworzenie Wojsk Obrony Terytorialnej, co związane jest z pewnymi przemianami kulturowymi.

Administrowanie sprawami personalnymi to jedna $z$ istotnych ról pełnionych przez menedżerów personalnych. W niniejszej publikacji rolę tę określono jako rolę eksperta administracyjnego. Zakres działań związany z administracją coraz 
częściej zostaje przeniesiony na inne działy organizacji, natomiast rola eksperta administracyjnego będzie polegała na skupieniu uwagi na bieżących (codziennych) potrzebach pracowników, słuchaniu, rozumieniu ich, inspirowaniu i ocenie. Badania jednak wskazują, że 85\% respondentów przypisuje im rolę administratora spraw personalnych (Piotrkowski, 2012, s. 110). Należy podkreślić, że zaobserwowano pewne tendencje do przejmowania niektórych zadań związanych $\mathrm{z}$ administrowaniem spraw personalnych przez komórki liniowe w miarę wkraczania informatyzacji w działalność organizacji (Piotrkowski, 2010, s. 227-237).

\section{Przesłanki konieczności kształcenia menedżerów personalnych w zakresie zarządzania kadrami w wojsku}

Uzawodowienie sił zbrojnych, czego dowodem jest w ostatnim dwudziestopięcioleciu przyjęcie modelu armii zawodowej - wzorowanej na rozwiązaniach występujących w zdecydowanej większości państw należących do NATO - wpływa na jej stan ilościowy i potencjał jakościowy. Kadra dowódcza i podlegli jej żołnierze stają się profesjonalistami o coraz wyższych kompetencjach. W sumie tworzą w ten sposób specyficzny, bardzo wykwalifikowany i jedyny w swoim rodzaju kapitał ludzki. W związku z tym istnieje konieczność jego określenia i umiejętnego nim gospodarowania. W szczególności chodzi o pozyskiwanie, utrzymanie wysokiego poziomu zaangażowania oraz rozwój kapitału ludzkiego armii. Niepodważalne jest, że umiejętne wykorzystanie kapitału ludzkiego poprzez profesjonale zarządzanie nim wpływa na bezpieczeństwo państwa. Stąd konieczność profesjonalnego zarządzania zasobami osobowymi Sił Zbrojnych RP jawi się jako jeden z ważnych nurtów nowoczesnego zarządzania w sektorze publicznym. Ocenę tę potwierdzają badania prowadzone od wielu lat przez Instytut Organizacji i Zarządzania Wydziału Cybernetyki WAT, które wpisują się w zamysł kształcenia kadr w zakresie zarządzania zasobami kadrowymi w Siłach Zbrojnych RP. Ich wyniki wyraźnie wskazują na konieczność profesjonalizacji działań personalnych ${ }^{5}$. Podobne wnioski, potwierdzające słuszność i konieczność kształcenia, formułowali słuchacze (oficerowie działów personalnych Sił Zbrojnych RP) Podyplomowych Studiów Zarządzania Zasobami Ludzkimi, posiadający doświadczenie w zakresie codziennej pragmatyki kadrowej. To wielopłaszczyznowe podejście do konieczności kształcenia poprzedzone licznymi badaniami i opiniami kierowniczej kadry dowódczej i kadry komórek personalnych

\footnotetext{
K. Piotrkowski, System zarządzania ludźmi w Siłach Zbrojnych RP, WAT, Warszawa 2012; K. Piotrkowski, Cechy szczególne zarzadzania w sektorze publicznym, WAT, Warszawa 2014; K. Piotrkowski, Raport $z$ przeprowadzonych badań $w$ ramach projektu ,Zarządzanie kapitałem ludzkim w Siłach Zbrojnych w świetle wspótczesnej wiedzy w zakresie zarzadzania", WAT, Warszawa 2016; K. Piotrkowski (red.), Zarządzanie kapitałem ludzkim w Siłach Zbrojnych RP, WAT, Warszawa 2016; K. Piotrkowski, Kompetencje kierowniczej kadry dowódczej w Siłach Zbrojnych RP, Warszawa 2017.
} 
wskazuje na potrzebę kształcenia przyszłych kadr w zakresie HR dla potrzeb sił zbrojnych i administracji terenowej resortu obrony narodowej, co przekłada się na najważniejszy aspekt, jakim jest bezpieczeństwo naszego państwa ${ }^{6}$. Argumentem uzasadniającym konieczność dalszej profesjonalizacji działań kadrowych jest także planowany wzrost liczebności armii ${ }^{7}$. Biorąc pod uwagę treści (założenia, kierunki) Strategicznego przegladu obronnego 2016, w tym model przyszłych Sił Zbrojnych RP, należy uwzględnić, że w ciągu najbliższych ośmiu lat liczba żołnierzy przekroczy 200 tys., wliczając w to służących w WOT ${ }^{8}$.

Należy podkreślić, że jednym $\mathrm{z}$ warunków sprawnego funkcjonowania tak licznej wyspecjalizowanej instytucji jest obok właściwego finansowania, skutecznego i klarownego systemu kierowania i dowodzenia, zaopatrzenia w nowoczesny sprzęt, także pozyskanie, utrzymanie i ich rozwój, tj. właściwe zarządzanie zasobami osobowymi. Dlatego też potrzebny jest wyspecjalizowany personel z zakresu zarządzania zasobami osobowymi na wszystkich szczeblach dowodzenia. Należy podkreślić również, że obecny system działań kadrowych zakłada pozyskiwanie na te stanowiska oficerów będących pierwotnie $\mathrm{z}$ wykształcenia specjalistami w innych dziedzinach wojskowych, przeszkolonych w ramach szkolenia kursowego lub studiów podyplomowych. Kształcenie takich specjalistów wydaje się o tyle zasadne, że szczególnie na pierwszych stanowiskach w komórkach właściwych w zakresie działalności kadrowej oficerowie realizują zadania w wielu obszarach (praca różnorodna). W miarę rozwoju zawodowego i pracy na kolejno wyższych szczeblach praca staje się bardziej jednorodna, wymaga wąskiej specjalizacji, stąd znacznie wzrasta odpowiedzialność za podejmowane decyzje. Natomiast analizując zadania stojące przed komórkami kadrowymi szczebla pododdziału, należy zwrócić uwagę, że oficerowie młodsi, będący również szefami tych komórek, w zależności od struktury organizacyjnej jednostki wojskowej oraz przyjętego w niej podziału odpowiedzialności często realizują zadania w obszarach działalności:

- $\quad$ kadrowej, mającej na celu stworzenie warunków do realizacji przez jednostki zadań zgodnie z przeznaczeniem, obejmującej rekrutację i selekcję, planowanie doskonalenia zawodowego i rozwoju zawodowego żołnierzy, wyznaczanie i zwalnianie ze stanowisk, ewidencję, jak również powoływanie i zwalnianie ze służby wojskowej;

6 K. Piotrkowski, Uzasadnienie powołania studiów wojskowych w WAT wakresie zrzadzania kadrami, Warszawa 2017.

7 Obecnie Siły Zbrojne RP liczą niespełna 130 tys. żołnierzy, w tym ok. 105 tys. żołnierzy zawodowych, 20 tys. Narodowych Sił Rezerwowych, 4 tys. kandydatów na żołnierzy zawodowych. Systematycznie wzrasta liczba ochotników w Wojskach Obrony Terytorialnej (WOT), z założeniem osiągnięcia do końca 2019 r. gotowości przez 17 brygad OT oraz stanu ok. 53 tys. żołnierzy. Jak też wynika z deklaracji ministra obrony narodowej, wojsko polskie zwiększy liczebność korpusu zawodowego do 200 tys. żołnierzy.

8 MON, Koncepcja obronna Rzeczypospolitej Polskiej, maj 2017, s. 52. 
- kadrowej obejmującej również pracowników wojska;

- finansowej, w zakresie uposażenia i innych należności pieniężnych żołnierzy i pracowników wojska;

- gotowości mobilizacyjnej, uzupełnienia potrzeb mobilizacyjnych jednostki w zakresie stanów osobowych;

- $\quad$ wychowawczej, w tym związanej z upowszechnianiem oraz kultywowaniem tradycji narodowych i orężnych;

- w zakresie dyscypliny wojskowej;

- $\quad$ komunikacji społecznej, zarówno wewnętrznej, jak i zewnętrznej.

Wymienione obszary działań kadrowych realizowane przez oficerów, poza przygotowaniem ogólnowojskowym i sztabowym, wymagają szerokiego zakresu wiedzy obejmującego kompetencje personalne, czyli zarządzanie procesami kadrowymi oraz wiedzę ogólną, np. z zakresu zarządzania, prawa, historii, ekonomii, psychologii i socjologii. Wymienione składniki kompetencji, czyli wiedza, umiejętności, doświadczenia oraz odpowiednie postawy i zachowania, powinny być nabywane na drodze studiów licencjackich i magisterskich z zakresu zarządzania zasobami ludzkimi o specjalności zarządzanie kadrami w wojsku oraz praktyki wojskowej, w tym dowódczej (szczebel plutonu, kompanii) dla poszczególnych rodzajów wojsk ${ }^{9}$, w których następnie po jej odbyciu byliby kierowani (zagospodarowani) w komórkach właściwych ds. kadr lub przenoszeni do struktur Wojewódzkich Sztabów Wojskowych (WSzW) czy Wojskowych Komend Uzupełnień (WKU). Należy podkreślić, mając na uwadze wyzwania stojące przed jednostkami administracji wojskowej stojącymi na pierwszej linii w kontakcie ze społecznością cywilną, w kontekście zwiększenia liczebności sił zbrojnych oraz gromadzenia i utrzymania właściwych rezerw osobowych, że wykwalifikowane w zakresie zarządzania zasobami ludzkimi kadry są niezbędne również tym instytucjom.

Wykształcony i gruntownie przygotowany personel zajmujący stanowiska w obszarze zarządzania zasobami ludzkimi (ZZL) już od najniższych szczebli dowodzenia zwiększałby gwarancję właściwej realizacji kierunków polityki kadrowej wyznaczanych przez kierownictwo resortu obrony narodowej, ale również trafnego diagnozowania problemów i potrzeb na szczeblu jednostki wojskowej i osiągania jej celów.

\section{Podsumowanie}

W strukturach zhierarchizowanych (wojskowych) ludzie stanowią jeden z najważniejszych zasobów organizacji. Dlatego też menedżerowie personalni w organizacjach wojskowych stanowią ważne ogniwo w systemie zarządzania zasobami

9 W rozumieniu art. 3 ust. 3 ustawy z 21 listopada 1967 r. o powszechnym obowiązku obrony Rzeczypospolitej Polskiej (Wojska Lądowe, Siły Powietrzne, Marynarka Wojenna, Wojska Specjalne, Wojska Obrony Terytorialnej). 
ludzkimi. Potwierdzają to badania prowadzone w tym zakresie oraz wyzwania stojące przed jednostkami administracji wojskowej w bezpośredniej styczności ze społecznością cywilną w kontekście systematycznego zwiększenia liczebności Sił Zbrojnych. Działania menedżerów personalnych obejmują: proces pozyskania, utrzymania (oddziaływania) i rozwój zawodowy pracowników (żołnierzy) oraz utrzymania odpowiedniej liczby rezerw osobowych. Stąd konieczność systematycznego i profesjonalnego przygotowania kadr w zakresie zarządzania zasobami ludzkimi, które są niezbędne dla sprawnego i właściwego funkcjonowania Sił Zbrojnych RP.

\section{LITERATURA}

[1] JarmoŁowicz W., Wynagrodzenia menedżerów w warunkach zmian systemowych, [w:] Problemy teorii i polityki ekonomicznej okresu transformacji, pr. zb. pod red. W. Jarmołowicza, Akademia Ekonomiczna, Poznań 2001.

[2] Kręcikij J., Wołejszo J., Podstawy dowodzenia, Akademia Obrony Narodowej, Warszawa 2007.

[3] Ріотвкоwsкi K., Specyficzne aspekty zarządzania zasobami ludzkimi w organizacjach wykorzystujacych technologię cyfrowa, [w:] Zarządzanie w warunkach gospodarki cyfrowej, WAT, Warszawa 2010 .

[4] Piotrkowski K., System zarządzania ludźmi w Siłach Zbrojnych RP, WAT, Warszawa 2012.

[5] Ріотrкошsкi K., Cechy szczególne zarządzania w sektorze publicznym, WAT, Warszawa 2014.

[6] Ріотвкоwsкi K., Raport z przeprowadzonych badań w ramach projektu ,Zarzadzanie kapitałem ludzkim w Siłach Zbrojnych w świetle wspótczesnej wiedzy w zakresie zarządzania", WAT, Warszawa 2016.

[7] Piотrкоwsкi K., Zarządzanie kapitałem ludzkim w Siłach Zbrojnych RP, WAT, Warszawa 2016.

[8] Ріотrкоwsкi K., Kompetencje menedżerskie kierowniczej kadry dowódczej w Siłach Zbrojnych $R P$, Warszawa 2017.

[9] Ріотrкоwsкi K., Uzasadnienie powołania studiów wojskowych $w$ WAT w zakresie zrzadzania kadrami, WAT, Warszawa 2017.

[10] Pocztowsкi A., Funkcja personalna. Diagnoza i kierunki zmian, Uniwersytet Ekonomiczny w Krakowie, Kraków 2017.

[11] Stoner J.A.F., Freeman R.E., Gilbert D.R., Kierowanie, PWN, Warszawa.

[12] Twardzik T., 2010, Zarządzanie zasobami ludzkimi. Zakres działań specjalistów, Ministerstwo Obrony Narodowej, Departament Kadr, Warszawa, www.kadry. wp. mil.pl, 2001

[13] Założenia polityki kadrowej w Siłach Zbrojnych RP, 2012, 2016, 2017, Ministerstwo Obrony Narodowej, Departament Kadr MON, Warszawa. 